Kevin M. McGeough*

\title{
Celluloid Esther: The Literary Carnivalesque as Transformed through the Lens of the Cinematic Epic
}

DOI 10.1515/jbr-2017-2004

\begin{abstract}
The reception of Esther has often been fraught with attempts to make the book more palatable to the audience receiving it and to interpret the book in a manner more consistent with the values of that community. This is evidence in cinematic adaptations of the book, where the story is transformed to better suit the genre expectations of the Biblical epic and the perspectives of the intended viewers. By examining two films based on Esther - Esther and the King (1960) and One Night with the King (2006) - some of the interpretive issues surrounding the tone and content of the Biblical source become apparent. If Esther is best understood as a carnivalesque work, as many scholars have suggested, then the expectations of this kind of work have not been met in the cinematic adaptations. Given the importance of film in contemporary Biblical reception, these new readings of Esther are perhaps particularly influential, at least within the restricted communities who view these movies. Likewise, analysis of these changes highlights the values of the makers of these films and the audiences who consume them.
\end{abstract}

Keywords: Esther; Cinematic adaptations of Esther; Biblical film; One Night with the King; Esther and the King; Biblical epic; Biblical adaptation.

\section{Introduction}

The history of Esther's reception has been fraught with divergent (often critical) evaluations of the book. ${ }^{1}$ The nature of that criticism though has been highly variable, rooted, of course, in the intellectual context of the individual reader and

1 For overviews see Jo Carruthers, Esther Through the Centuries, Blackwell Bible Commentaries (Malden, Massachusetts: Blackwell Publishing, 2008), 1-10; and Carey A Moore, Esther: Introduction, Translation, and Notes (AB 7B, Garden City, New York: Doubleday, 1971), xvi.

*Corresponding author: Kevin K. McGeough, Professor of Archaeology, Department of Geography, University of Lethbridge, Lethbridge, Alberta, Canada, e-mail: mcgekm@uleth.ca 
community. As is well known, no copy of Esther was found amongst the Dead Sea Scrolls and many scholars believe that this is not accidental. ${ }^{2}$ The status of the book in Rabbinic Judaism and early Christianity was also disputed. ${ }^{3}$ Reformation era scholars also disapproved of the work. Martin Luther famously lamented what he saw as Judaic and pagan elements of the work, and wished that the book did not exist. John Calvin tried to will it into non-existence by not offering a commentary on it and rarely citing it. Perhaps it is the absence of God in the Hebrew original, the prominence of women, or the call for genocide that inspired so much disdain in pre and early modern scholarship but the mixed reviews have continued well into the 21st century. Linda Day has argued that much of this criticism has been antisemitic in tone, reading the violence of the narrative as a fundamental feature of Judaism rather than as a reaction to a dangerous situation. Gender issues have been similarly controversial. ${ }^{4}$ Even the advent of feminist hermeneutics did not stem the criticism of the book, with second wave feminists in particular arguing that Esther's actions supported a patriarchal power structure. ${ }^{5}$ Jo Carruthers has argued that much of the reception history of Esther has revolved around trying to redeem the book from those aspects that make the reader uncomfortable. ${ }^{6}$ This tradition of trying to remake Esther into a story that better conforms to the norms of the audience is quite evident in its cinematic adaptations, which diverge markedly from the source material in characterization, plot elements, and especially tone and mood. Adapting Esther to cinema allows the difficult elements of the text to be made more palatable and more consistent with audience expectations of biblical story telling. The issue of the transformation of Esther into film is explored here in two examples of the biblical epic genre that were produced in different cinematic contexts: Esther and the King (1960) and One Night with

2 Adele Berlin, Esther [= Ester]: The Traditional Hebrew Text with the New JPS Translation, JPS Bible Commentary (Philadelphia: Jewish Publication Society, 2001), xliv; John Jarick, "The Bible's 'Festival Scrolls' among the Dead Sea Scrolls,” in The Scrolls and the Scriptures: Qumran Fifty Years Later, eds. Stanley E. Porter and Craig A. Evans, Journal for the Study of the Pseudepigrapha Supplement Series 26, Roehampton Institute London Papers 3 (Sheffield: Sheffield Academic Press, 1997): 179-82.

3 For an introduction to the evidence for this see Berlin, Esther, xliii-xlv; and Moore, Esther, $\mathrm{xxx}-\mathrm{xxxiv}$.

4 Linda Day, Esther, Abingdon Old Testament Commentaries (Nashville: Abingdon Press, 2005), 21; Jo Carruthers, Esther Through the Centuries, Blackwell Bible Commentaries (Malden, Massachusetts: Blackwell Publishing, 2008), 3.

5 For an overview and evaluation of some of these critiques, see Sidnie Ann White Crawford, "Esther," in Women's Bible Commentary, eds. Carol A. Newsom and Sharon H. Ringe (Louisville: Westminster John Knox, 1998): 124-9.

6 Carruthers, Esther, 2-7. 
the King (2006). Given the popularity of film, cinematic interpretations of biblical stories are particularly revealing of normative expectations of the biblical text. Furthermore, given the power of movies to present convincing visions of antiquity, these cinematic reformulations can further reify these expectations of the biblical text. What is apparent in the Esther interpretations is that the filmmakers have difficulties dealing with the tone and content of Esther, in the same way that many earlier interpreters have struggled with the book. These cinematic attempts to make the story conform to certain genre expectations reveal the normative values that the filmmakers want the book to uphold.

Looking at the particular aspects of Esther that are changed for cinema sheds light on where interpreters struggle with the divergence between tonal and narrative expectations of the Bible and the complexities that are apparent in close readings of the book. Through film, non-specialists have crafted versions of Esther that reflect the book that they wish existed. However, as with all readings, this interpretation is embedded within its unique historical and cultural context and so these reformulations point to the ways through which different communities struggle with problems that they see in the text. In her consideration of filmic exegesis, Rhonda Burnette-Bletsch has argued that film is a particularly powerful means through which people encounter biblical stories: ${ }^{7}$

It is probable that in today's world more people are exposed to and influenced by filmic representations of the Bible than by scholarly or confessional commentary. It is clear that film, in all of its modern-day incarnations, has become an extremely powerful vehicle for the cultural production and dissemination of biblical texts and the creation of meaning from these texts by active readers situated within particular social and historical contexts.

Burnette-Bletsch's premise that cinematic adaptations of the Bible constitute biblical reception and that filmmakers should be considered serious interpreters of the Bible means that scholars should be cognizant of the specific strategies that these interpreters bring to bear on the text. ${ }^{8}$ Each individual's experiences are different and Burnette-Bletsch does not argue for a one-sided attempt at understanding a filmmaker's intention, explaining that other film theorists have shown that viewers also participate in the creation of a film's meaning. ${ }^{9}$ Rather, she argues that a reception approach can: "consider how biblical texts might be (re) produced and interpreted by filmmakers and film-viewers operating in particular

7 Rhonda Burnette-Bletsch, "The Bible and Its Cinematic Adaptations: A Consideration of Filmic Exegesis," Journal of the Bible and its Reception 1, no. 1 (2014), 129-60, 130.

8 Burnette-Bletsch, "The Bible and Its Cinematic Adaptations": 142.

9 Burnette-Bletsch, "The Bible and Its Cinematic Adaptations": 153. 
cultural contexts." 10 Thus cinematic biblical stories inspire new ways of making sense of the texts and inform new readings.

While viewers will not necessarily accept all that they see on film uncritically, the materially convincing nature of the genre leads audiences to take away certain messages about the nature of antiquity and its relationship to the present. ${ }^{11}$ Carruthers' argues that a "stealth narrative" is present in Esther and the King, which offers other messages that are, "not necessarily apparent enough to provoke thoughtful reflection." ${ }^{12}$ Such narratives are usually present in film and their lack of immediate transparency can be problematic. Film's power as a form of mass media also means that these messages are conveyed to much larger communities than other forms of biblical interpretation. Jerry Mander's influential argument about how television undermines imagination is important here, for he has demonstrated the difficulties that viewers have in differentiating between mental images derived from personal experience and those derived from television-viewing, arguing that, for example, it is not possible to think of ancient Rome without imagining a cinematic representation. ${ }^{13}$

\section{Questions of Genre}

One could argue that cinema transforms a potentially subversive biblical story like Esther (especially subversive in terms of its attitudes towards issues of governance and gender), into a fundamentally conservative form. Yet, perhaps it is more accurate to read biblical Esther as a carnivalesque work, and thus a product of popular culture that is essentially conservative in its original context. Carnivalesque works are often humorous and seem subversive given the treatments of political and social power in these kinds of stories. Gender norms are commonly overturned, the powerful are made weak and the subaltern gain greater agency. Yet the carnivalesque actually fulfills a more conservative impulse in that by presenting a temporary inversion of social and political roles, it actually reifies them. In that case, a cinematic adaptation

10 Burnette-Bletsch, “The Bible and Its Cinematic Adaptations": 154.

11 Kevin M. McGeough, "Heroes, Mummies, and Treasure: Near Eastern Archaeology in the Movies,” Near Eastern Archaeology 69, (2006), 174-85.

12 Jo Carruthers, "Biblical Epic and the American State: The Traitor and Sanctified Violence in Esther and the King (1960)," in Holy Terror: Understanding Religion and Violence in Popular Culture, eds. Eric S. Christianson and Hugh Partridge, (Sheffield: Equinox, 2010), 42-52, 48.

13 Jerry Mander, Four Arguments for the Elimination of Television (New York: Morrow Quill Paperbacks, 1978), 243-6. 
of a carnivalesque story into a more staid genre merely constitutes a different product of popular conservatism and functions to uphold a different status quo. While cinema can use carnivalesque techniques to make similarly conservative arguments while seeming to push boundaries, audiences expect more serious seeming treatments of the Bible. When filmmakers have deviated in expected tone, some groups have been vocal in expressing their displeasure, as was the case with The Life of Brian (1979) and The Last Temptation of Christ (1988). Tone, the attitude of the filmmakers towards the subject, is especially risky when dealing with religious topics. So, for filmmakers wishing to avoid such controversy, it is safer to create movies that conform to genre expectations that have been established in earlier films.

In examining the transformation of a story from one media to another, the issue of genre is important, since the rules of a genre condition readings of the text. Form critical approaches to biblical studies since Hermann Gunkel's recognition of the importance of Sitz im Leben have presumed a relationship between the genre of a story and its reception. Questions of genre have long plagued Esther scholars and while there is no need to survey the complexities of those issues here, ${ }^{14}$ this may have a bearing on understanding how this story has been transformed into film. For if biblical scholars cannot agree on the genre of the book, should it be expected that other types of readers will offer fully consistent readings of the story when transposing it into an alternate genre? That is to say, if different readers identify divergent tropes within the same story, it cannot be expected that reformulations of that story will be consistent. In the absence of clear-cut, unambiguous source material, the translators may prefer to smooth over these difficulties in their new version of the story.

Perhaps one of the most difficult aspects of Esther for its many critics over the centuries is its humor. This is a biblical book, a sacred book within the canon, and part of the devotional life of Jews and Christians alike, and so humor, especially for a story fraught with violence, is not expected. Yet in recent years, commentators agree that this is one of the fundamental features of the book. Jon Levenson, in his commentary to Esther, explores the comic elements of the book in depth. ${ }^{15}$ Linda Day has shown how humor is central to the book's narrativity. ${ }^{16}$

14 Frederic Bush, Ruth/Esther, Word Biblical Commentary 9 (Dallas: Word Books Publisher, 1996), 297-309; Day, Esther, 11-12; Kevin M. McGeough, “Esther the Hero: Going beyond 'Wisdom' in Heroic Narratives," Catholic Biblical Quarterly 70 (2008), 44-65, 45-8.

15 Jon D. Levenson, Esther, Old Testament Library (OTL) (Louisville: Westminster John Knox, 1997), 12-14.

16 Day, Esther, 5. 
Timothy Beal has likewise emphasized the farcical elements in relation to issues of identity, ${ }^{17}$ and numerous other commentators have explored the different types of humor in the story. ${ }^{18}$ The humor is recognized in Jewish traditions, in its central role in the holiday of Purim. Yet that same humor has made the book, at times, unacceptable to Christian and especially Protestant readers. Berlin argues that much of the story could be deemed burlesque, which is not typically a genre that has been embraced by conservative elements within Protestantism, the faith community to which the cinematic adaptations of Esther have been most directly aimed. ${ }^{19}$

As has been noted by many commentators, the inversion of political life and gender roles are fundamental to the story of Esther. In Esther, the women of the story play central roles and there is good literary reason for why the book is called Esther. There has been much discussion over the role of gender in Esther and the book lends itself to ambiguous interpretations. Sidnie White Crawford, Linda Day, and I have argued that Esther is an heroic figure, perhaps intended for emulation. ${ }^{20}$ Lillian Klein and Claudia Camp have illustrated how the book presents creative means through which women can act within the existing normative framework. ${ }^{21}$ The plot of the story hinges on various actions that women take in response to what they perceive to be as immoral or irresponsible applications of power. These are moments of direct resistance by women against the men to whom they are subordinate to in the political hierarchy.

Power and hierarchy are seemingly contested and subverted in the book, but the presentation is more complex than that. One of the most readily apparent themes in the book of Esther is a critique of Persian imperial governance and bureaucracy more generally. Levenson explains how this critique is related to the humor of the story and the portrayal of King Ahasuerus:

He [the king] is portrayed as a man of inordinate official power but no moral strength. His regime is enormously bureaucratized, yet he lacks all personal complexity. It is this disparity between the office and the man, between what he decrees and what actually happens,

17 Timothy K. Beal, The Book of Hiding: Gender, Ethnicity, Annihilation, and Esther (New York: Routledge, 1997), ix.

18 For a more complete list see Berlin, Esther, xix-xx.

19 Berlin, Esther, xix-xx.

20 Sidnie Ann White Crawford. "Esther: A Feminine Model for Jewish Diaspora," in Gender and Difference in Ancient Israel, ed. Peggy L. Day (Minneapolis: Fortress, 1989), 164; McGeough, "Esther the Hero"; Day, Esther, 240.

21 Lillian R Klein, From Deborah to Esther: Sexual Politics in the Hebrew Bible (Minneapolis: Fortress, 2003), 118; Claudia V. Camp, Wisdom and the Feminine in the Book of Proverbs, Bible and Literature Series 11 (Sheffield: Sheffield Academic Press, 1985), 124. 
that imparts to the book many of its funniest scenes. But underneath the humor is a belief that the imperial administration is overblown, pompous, over-bureaucratized, and, for all its trappings of power, unable to control events. ${ }^{22}$

Levenson examines how the portrayal of the Persian court provides a critique of the Persian government and other commentators are in broad agreement with this. The critique is not necessarily a straightforward dismissal of governance per se. Rather, it exaggerates the complicated bureaucracy of Persia and the illogical force of law once decreed. Similarly, kingship is not inherently negative in this vision of governance. What is actually critiqued, which is common in political discourse, is the power of the king's advisors and the corruption of those advisors. Government is not bad in Esther but poor governance is shown to be profoundly dangerous.

Given the critique of the status quo, the story is still better understood as largely conservative, given the nature of the literary carnivalesque. Here I follow one of the most influential readings of Esther in recent decades: Kenneth Craig's application of Mikhail Bakhtin's notion of the carnivalesque. For Bakhtin, the carnivalesque is a mode of subverting dominant narratives and power structures through humorous and/or chaotic representations. The carnival is a liminal time when the world is turned upside down and social actions that are usually transgressive become allowed, both helping to define the boundaries of established conventions and potentially pushing against them. Craig argues that the book of Esther should be categorized as carnivalesque since it is a work that celebrates a temporary inversion of social power and norms yet by doing so reifies those same social norms. ${ }^{23}$ It gives temporary voice to disempowered groups and briefly subverts the normative power structures within a given society. That the story involves violence and destruction on a massive scale is part of its carnivalesque nature, for wanton destruction is part and parcel of this kind of story-telling. In Esther's case, the carnivalesque atmosphere is enacted within the context of the exile of the Jews under the Persian empire and allows, at least for the duration of the story, a moment when the Jews are able to achieve dominance within the larger power structures of the state, despite (or because of) their minority status. Other commentators on Esther have embraced this reading of the book, ${ }^{24}$ which is particularly fitting given the liturgical use of the story in the celebration of Purim.

22 Levenson, Esther, 12.

23 Kenneth Craig, Reading Esther: A Case for the Literary Carnivalesque (Louisville: Westminster John Knox, 1995), 33.

24 See, for example, Berlin, Esther, xvi-xxii. 


\section{The Biblical Epic}

The cinematic adaptations of Esther do not capture the carnivalesque feeling of the biblical story. If anything, they seem to misunderstand the comedy of the story and the situations. In part, this is due to genre elements of the biblical epic as it developed in the 1950s, which treated the biblical stories as somber, serious, historical drama, and in which biblical stories were adapted to suit these requirements. In the aftermath of the success of DeMille's second version of The Ten Commandments (1956) and William Wyler's Academy Award winning Ben-Hur: A Tale of the Christ (1959), biblical, Egyptian, and Roman historical epics became the type of prestige pieces that studios were willing to expend huge budgets on, in hopes of differentiating movies from television and attracting international audiences. Bruce Babington and Peter William Evens, following Gilles Deleuze, have shown that this genre of film takes a view of history that is fundamentally analogical to its contemporary American society and that, given the lack of generic depth (as opposed to, in their example, the Western), is particularly susceptible to shifts in ideology. ${ }^{25}$ Babington and Evans settle on the term 'Biblical Epic' for films dealing with the Old and New Testament as well as the early Church, but recognize that this is not entirely satisfactory even though it reflects common usage. ${ }^{26}$ For Babington and Evans, these films are epic because they deal with turning points in world history and treat them on a massive scale, both financially and in terms of historical significance. In the specific case of the biblical epic, there is a sort of ecumenism that is, not so much a direct theological argument, but a reflection of the American mass culture of the era and the wider world audience at whom the films were aimed. ${ }^{27}$ As a means of religious expression, biblical epics are unique since they present religious stories in a form (film) that did not emerge from a theological context. ${ }^{28}$ The biblical epic film was and is story-telling for the middle class, for the presumed Protestant audiences seeking some semblance of normativity in a post-war context. Richard Walsh has argued that the Protestant family was the major market for these films in the 1950s and the changes in the composition of the film-going audience that occurred over the course of the 1960s led to the decline of this particular style of film. ${ }^{29}$ He points

25 Bruce Babington and Peter William Evans, Biblical Epics: Sacred Narrative in the Hollywood Cinema (Manchester: Manchester University Press, 1993), 6, 11-12.

26 Babington and Evans, Biblical Epics, 4-6.

27 Babington and Evans, Biblical Epics, 14.

28 Babington and Evans, Biblical Epics, 16.

29 Richard Walsh, Reading the Gospels in the Dark: Portrayals of Jesus in Film (New York: Trinity Press International, 2003), 2-3. 
to cinematic elements of the films (such as militaristic figures gradually embracing pacifism and domesticity) as mirroring the social situation of many American audience members of the era. ${ }^{30}$

Babington and Evans have shown that even though many of the producers who supported these films were Jewish, they were conservative Republicans who were committed to an assimilationist approach to life in the United States. ${ }^{31}$ Biblical epics are not celebrations of a minority group temporarily achieving power; rather, they are tales where a minority group begins its teleological movement towards domination. These films are the origin stories of Protestant, middle-class Americans, of which more will be discussed below. As shall be shown, the cinematic adaptations of Esther discussed here concentrate not so much on minority rights but on the assimilation of minority groups into the larger power structures of the dominant polity. Typically, the protagonists are marginalized and the endings of biblical epics are often unhappy for those characters. Yet the endings point to a longer historical trajectory where the values espoused by the protagonists will eventually become normative. Thus the story of Esther, to fit within this genre, needs to be stripped of its carnivalesque characterizations and plotting.

Perhaps the most difficult element of Esther to be adapted to the genre of the biblical epic is mood, the atmosphere of the book, which in Esther's case is more ribald and comic than the solemn mood audiences might expect of a biblical story. This problem is not unique to This problem is not unique to Esther; as mentioned above, capturing an appropriate tone in biblical dramatization has often been difficult. Biblical theatre was long banned in Great Britain out of concern for the potential for blasphemy. ${ }^{32}$ With the birth of film, a certain freedom regarding biblical representation lasted until the controversial The Sign of the Cross (1932) pushed the limits too far. The Hollywood Production Code (often called the Hays Code) that was published in 1930, forbade the irreverent treatment of religion and after The Sign of the Cross, came to be enforced in relation to biblical film. Given the irreverence of Esther, a literal adaption of the work could not readily fulfill the proscriptions of this code. The heroes kill without consequences, potentially immoral sexual activities (implied through the king's harem) are suggested, white slavery could be inferred, and negative depictions of social and political institutions are advanced. These plot points or characteristics are prohibited or

30 Walsh, Reading the Gospels, 127.

31 Babington and Evans, Biblical Epics, 34.

32 Kevin M. McGeough, The Ancient Near East in the Nineteenth Century, Appreciations and Appropriations: Volume III: Fantasy and Alternative Histories. Hebrew Bible Monographs 69 (Sheffield: Sheffield Phoenix Press, 2015), 71-2. 
questioned under the Hays code, which also requests that religion be treated respectfully and other nations or groups be depicted favorably. Directly filming many of the narrative elements of the Biblical book could potentially have been seen to violate the production code in any number of ways. Even though the influence of this code on Biblical epics had begun to wane by the heyday of the biblical epic in the 1950s, the tensions between literalism and virtuous portrayals seemed to have still been problematic and some of the fundamental elements of the code continued to be built into the big budget films of the era.

These big budget films needed to conform to audience expectations of the Bible, at least in mood if not in narrative content. Carnivalesque stories have the feel of subversion but are, in practice, conservative works that reify the status quo. The status quo is questioned and critiqued, through explorations of inversion but it is understood by all that these inversions are only temporary. The criticisms are seemingly edgy, but take place in liminal situations where the expectation is that all will be made normal again. Resistance by the subaltern is allowed but only in restricted manners and the exercise of this resistance in practice reifies and defines the boundaries that are being tested. The biblical epic film is one of those locations where satire about the state and dominant power structures is unwanted or unsafe since the argument of the film is that the power structures that eventually emerge are divinely ordained. The implied political history that will proceed after the biblical story concludes is that democratic governance will become the natural mode of governance, emerging from various older forms of monarchical leadership. Similarly, the gender roles that come to be asserted in the 1950s are seen as normative for the culture of the protagonists of the biblical epic but the deviant gender roles amongst the "others" in the films mark those "others" as decadent and immoral. These themes of contested gender roles and power structures enacted in a carnivalesque manner seem well suited for the cinema. The farcical misunderstandings, the excessive violence, the bawdy humor all seem perfectly suited for dramatic adaptation, like a Shakespearean comedy. Lisa Wolfe, in her discussion of the genre of Esther has even emphasized the seeming cinematic qualities of the book, writing: "I like to think of Esther as an historicized tale, as if told by filmmaker Tim Burton, where everything is exaggerated." 33 The problem, perhaps, is not so much the story itself but the nature of the genre of the biblical epic, especially as the genre tropes become established in the American cinema of the 1950s and 1960s.

33 Lisa M. Wolfe, Ruth, Esther, Song of Songs, and Judith (Eugene, Oregon: Cascade Books, 2011), 67. 
Biblical epics offer what Babington and Evans, softening Paul Schraeder's argument, refer to as a "false syllogism." 34 The film makes a claim for truth, religious events are presented on film, and so the audience concludes that the religious event is historical. Part of the problem with transforming Esther into a biblical epic is the ahistorical nature of the work since that film genre demands an aesthetic of historicity and archaeological veritas (even if seldom actually obtained). All but the most conservative of scholars agree that Esther was not intended to be an historically accurate recounting of real events that occurred in the Persian court. ${ }^{35}$ Yet much of the point of the Biblical epic as a genre is to offer an historical vision of another time and place and the genre typically uses a number of tropes to convince the audience of its historicity (although this is not always successful). Many of the comedic, literary elements of Esther do not lend themselves well to this particular mode of filmmaking and so either those story elements need to be changed or the genre needs to be altered in some manner to accommodate this. While the backdrop of the films is an historically "other" setting, the characterizations are rooted in the operatic traditions of historical narrative. Indeed, many of the characterizations and plot structures that are used in cinema to adapt biblical stories into theatrical forms were first used in 19th-century biblical opera. ${ }^{36}$ The features of the Victorian stage melodrama were particularly influential in the development of biblical cinematic representations; Babington and Evans argue that these were directly adapted by D.W. Griffith for Intolerance, which proved influential for much later biblical filmmaking. ${ }^{37}$ Richard Walsh has called these films melodramas and that designation accurately reflects the kinds of characterizations that are found in these movies. In melodramas, plot takes precedence over characterization, which is often limited to stereotypical or stock characters. ${ }^{38}$ Ben Singer identifies other typical features of melodrama: an extreme polarization between good and evil, an emphasis on violence and action, and the preponderance of otherwise unbelievable coincidence in the advancement of the plot. ${ }^{39}$

34 Babington and Evans, Biblical Epics, 15.

35 Berlin, Esther, xvi-xvii; Levenson, Esther, 23-7.

36 McGeough, The Ancient Near East, Volume III, 136-87.

37 Babington and Evans, Biblical Epics, 17.

38 Walsh, Reading the Gospels, 21-2.

39 Ben Singer, Melodrama and Modernity: Early Sensational Cinema and its Contexts (New York: Columbia University Press, 2001), 44-53. 


\section{Teleology and Ideology in the Biblical Epic}

Perhaps it is most evident in the works of Cecil B. DeMille, but underlying Biblical epic cinema is a teleological conception of history. In DeMille's films, it is apparent that American democracy is understood to be the culmination of history, that it is the final stage in a series of political processes that are initiated in biblical times by biblical figures. ${ }^{40}$ In epics of this era, generally, Egypt, Rome, Mesopotamia, and Persia are all authoritarian empires (depicted varyingly in reference to World War II era fascism or Cold War Era communism) that the biblical characters struggle against. Thus the Biblical epic presents typological stories of conflicts in the present played out in ancient settings, a form of biblical interpretation that Hans Frei has characterized as 'precritical'. ${ }^{41}$ The values of American liberty and democracy, when presented typologically, are reified as eternal and fundamental truths. Many of these films emphasize the willingness of characters to sacrifice themselves for the greater good, a sacrifice that audience members who had lived through the war years would be able to appreciate.

It is not just liberty and democracy that are shown to be typological in biblical epics but the social norms of the 1950s and 1960s, made manifest cinematically in ancient settings..$^{42}$ Contemporary values and practices seem to be justified by biblical antecedent through these movies even when those norms are nowhere to be found in the original source material. When the publicity surrounding a film highlights it as biblical, and filmmakers adopt the cinematic conventions that convey historicity and accuracy, there is a misleading claim to biblical authority. As Burnette-Bletsch notes, these cinematic renderings of biblical stories often lead to new popular conceptions of the biblical world that have limited biblical, historical, or archaeological justification:

[T]hese films simply imitate the producing culture's popular conceptions of the biblical world and its characters, which have often included elements of orientalism (especially in American and European films) and a tendency to reimagine biblical heroes in line with that culture's values and aesthetic ideals. ${ }^{43}$

Gender roles in particular, which shall be discussed in greater detail below, particularly reflect the normative construct of the era of the filmmakers. For a

40 Carruthers, "Biblical Epic”, 36; Gerald E. Forshey, American Religious and Biblical Spectaculars (Media and Society Series. Westport, Connecticut: Praeger, 1992), 9, 28, 200.

41 Hans Frei, The Eclipse of Biblical Narrative: A Study of Eighteenth and Nineteenth Century Hermeneutics (New Haven: Yale University Press, 1974), 153.

42 Carruthers, "Biblical Epic", 43.

43 Burnette-Bletsch, "The Bible and Its Cinematic Adaptations", 142-3. 
book like Esther, which offers potentially destabilizing visions of gender roles, the cinematic treatment of masculinity and femininity is fraught with potential difficulty.

Although the ideological force of the films seems to best exemplify American values, it would be a mistake to think of these films as solely Hollywood productions. Given the costly nature of these epics and the necessity of filming in exotic locales, there was quite a bit of international collaboration in the making of these films. Italy in particular developed a film industry that worked in tandem with Hollywood to produce major historical spectacles and so often these biblical epics were overseen by Italian directors, staffed by Italian crews and populated with Italian actors. ${ }^{44}$ Indeed, both films that are the subject of this analysis were filmed outside of a Hollywood context, although it is apparent that the international casts and crews of the two movies were working to create pictures in the Hollywood epic style. At this point, it is useful to look at the specific transformations of Esther in particular cinematic adaptations in order to understand how these portrayals dramatically transform the narrative elements of the Biblical story but retain an ideological conservatism that upholds normative practices.

\section{Esther and the King (1960)}

Esther and the King (1960), directed by Raoul Walsh and starring Joan Collins and Richard Egan is now mostly forgotten, and the film's original tagline, "The Most Celebrated Love Adventure of All ... From the Greatest Book of All” seems at odds with any potential reading of the biblical original. With its expanded romance story and operatic characters, it is one of numerous biblical adaptions produced in the 1950s and, on initial viewing, plays like many of its contemporary biblical films. The approaches to biblical adaptation used in Walsh's film illustrate much about this particular genre and era of film-making. Yet given the unique features of the book of Esther already noted, the approaches that are successful for refashioning other biblical books into movies are more problematic here. On the whole, the film only reflects the biblical story of Esther on a surface level and transforms much of the ancient tale in a way that is specific to this era of biblical film-making. Of course, such deviations to well known biblical stories are not

44 For more on the Italian historical film-making of the time, see Joanna Paul, Film and the Classical Epic Tradition (Oxford: Oxford University Press, 2013), 22. 
always successful in capturing audience interest since the crowd that the films are marketed to expects a certain level of verisimilitude with the source material.

Esther and the King was one of the many Italian-American co-produced ancient epic films of the era. The filming of Quo Vadis? (1951) in Rome had inaugurated a new era of joint American-Italian film-making that built on Italy's older tradition of epic film-making that dates back to the silent film days. Raul Walsh is usually credited as director but Mario Bava (one of the most important figures in Italian horror films and one of the creators of the slasher genre) was the director of photography and it represents his creative vision as well. In fact, Italian prints of the film give Bava a co-director's credit. Bava had worked on the 1957 Italian version of Hercules starring Steve Reeves and had assistant director credit on the 1959 sequel, Hercules Unchained, so was well-versed in the production elements of this style of melodramatic ancient story. Since Bava was particularly notorious for rewriting the script on the spot, many of the idiosyncrasies of the narrative may be due to his auteur approach to filmmaking.

Like the Biblical story, Esther and the King establishes the setting within a specific historical era that is known to the audience but distant to them. It could be argued that the original book presumes that readers were familiar with the Persian empire but that they were living elsewhere or at a later time, otherwise the various informative glosses about Persia make little sense..$^{45}$ It opens with a formulaic seeming historical notice about King Ahasuerus (Esth 1:1) and the kingdom over which he ruled. Esther and the King captures this feeling readily, which is, of course, one of the conceits of the genre of the biblical epic more broadly. Perhaps what differs though is that the film makes an effort to situate the story within a realistic historical framework, opening with a narrator's voice explaining the context while the camera pans over a large army on the move. That being said, neither version of the story is particularly concerned with historical verisimilitude and historical-critical problems are readily and immediately apparent. The reference to historical time but lack of concern for historical accuracy points to the melodramatic nature of both versions of the story; the narratives are set in another time and place and it is that otherness that is key, not the specificity that comes with historical precision. Both stories are tales of how the actions of individuals play out across historical time and impact the changing fortunes of larger nations. The difference is that the biblical story seems to be historically inaccurate as part of a literary strategy; the film is just sloppily inaccurate.

Despite the similarities in flexibility surrounding historicity, the film immediately deviates from its source material, and these deviations illustrate some of

45 Levenson, Esther, 26. 
the ways in which the biblical book was deemed unpalatable to 1950s and 1960s audiences and some of the demands made by the transformation of the book of Esther into this particular genre. The major plot points of the film are reminiscent of the biblical story but, without the explicit character names as referents, the story would be unrecognizable as that of Esther. What is most strikingly different are a number of character inversions and inventions from the biblical original in Esther and the King. Most apparent are the treatments of King Ahasuerus and Queen Vashti, whose portrayals are opposite to those in the biblical story.

The Biblical king Ahasuerus is a drunken boor, a figure of comic relief, susceptible to the influences of his immoral advisors and unable to control his temper and appetite. Most commentators agree on this reading of the king. ${ }^{46} \mathrm{He}$ is not a central figure from a narrative standpoint; rather, he is a force that is manipulated by the protagonists and antagonists. There is little about Richard Egan's portrayal of Ahasuerus that is recognizable from the biblical character but it is consistent with other attempts to read the character of the king as admirable, especially by Christian commentators living within a monarchical state..$^{47}$ For the film, the king is made into the hero, a central figure and one of the main characters through which the audience sympathizes. Carruthers sees this as part of a transformation of the characters of the story into a literary triad of victim, victimizer, and rescuer. ${ }^{48}$ The king becomes the rescuer. Ahasuerus is a noble, sober king, a virtuous and kind leader and not prone to excess. He is a responsible military leader, who shows deep concern for his people and soldiers as is typical of the genre. He is presented as an American-style hero. Jon Solomon comments that Egan's portrayal was seen as problematic even in 1960, citing New York Times film reviewer Bosley Crowther's comments that, "Richard Egan looks about as Persian as an offensive back on the Baltimore Colts." 49

The dissimilarities between the two kings signals one of the fundamental differences between the book and the film. As already noted, the biblical original offers a carnivalesque satire of the bureaucratized state and presents the Persian government as Kafka-esque. As already discussed, there are many other ways in which Ahaseurus's government is presented in a comically negative light in the biblical original. Biblical epics are not typically subversive of the state, and a comedic take on bad governance would not suit the genre. In most instances, the

46 See, e.g. Berlin, Esther, xx; Bush, Ruth/Esther, 316; Day, Esther, 5-6; Levenson, Esther, 12-4; Moore, Esther, 14.

47 Carruthers, Esther, 55.

48 Jo Carruthers, "Biblical Epic", 49-50.

49 Jon Solomon, The Ancient World in the Cinema, Revised and expanded edition (New Haven: Yale University Press, 2001), 253. 
biblical epic reifies contemporary power structures in a somber fashion and especially in the post-war context of the 1950s and 1960s Hollywood epic, offers reflections on the importance of military service for the greater good of one's nation. The king is the embodiment of the virtuous state and King Ahasuerus is the type of ruler any citizen would long to serve.

In Esther and the King, the problems with the state are problems caused by corrupt advisors who seek to serve themselves at the expense of the state and seek to gain office through illegal means. In this film, Haman is sensibly cast in this role. Carruthers sees Haman's character in this film as representative of the traitor to the state and argues that this provides the key to understanding the film, which she describes as a Cold War era "exploration of treason through the stance of the godly Esther against the traitorous 'prince' Haman." ${ }^{50}$ Unlike the Biblical story, the film portrays Haman's behavior as atypical of the administration. He is the weak link in governance. Like numerous iterations of the Robin Hood story, Haman is akin to the immoral King John who oppresses the people while the noble King Richard is away fighting the crusades. In Esther and the King, it is the Egyptians who Ahasuerus has been off fighting, allowing Haman the opportunity to mistreat the people of Persia. The nature of the offences of the state are also similar to those from Robin Hood stories and as Carruthers points out, ${ }^{51}$ Haman executes those who cannot pay their taxes. Esther reforms these taxation practices so that ability to pay, not a flat rate, is the basis of the assessment (a concern for financial practices not found in the biblical original).

Character inversions such as Ahasuerus's are not uncommon in biblical cinema, especially in regards to royal figures. Perhaps the earliest of these kinds of changes was D.W. Griffith's take on Belshazzar in his 1916 Intolerance. Typically taken as either a dangerous enemy of the Jews or a drunken glutton who allowed his kingdom to fall while he enjoyed the pleasures of the senses, Griffith's Belshazzar is described in an intertitle as an, "apostle of tolerance and religious freedom." Shepherd has shown that in this divergent reception of Belshazzar, the Babylonian king is depicted as a "parallel characterization" of Christ, whose story is also presented in the film. ${ }^{52}$ Both figures are the victims of intolerance. With Belshazzar now the hero, Griffith must make Cyrus the enemy, also in disagreement with traditional biblical reception. Shepherd argues that this serves Griffith's larger antisemitic message (since the director also emphasizes Jewish participation in the

50 Carruthers, "Biblical Epic”, 42.

51 Carruthers, Esther, 127.

52 David J. Shepherd, The Bible on Silent Film: Spectacle, Story and Scripture in the Early Cinema (Cambridge: Cambridge University Press, 2013), 180-1. 
crucifixion in the parallel New Testament story in the film). ${ }^{53}$ Following Griffith's film, such character inversions became commonplace in biblical filmmaking.

Haman's foil, like in the Bible, is Esther's uncle Mordecai, who is portrayed in the film as a just and morally upright advisor to the king (a step up from his station in the biblical book). Unlike Haman, Mordecai works hard, prays frequently, and has disdain for the pleasures of banqueting. His values are distinctly neo-liberal and what he wants for Persia is a society that is marked by all the benefits that capitalism can bring. Unlike the biblical version of Esther's uncle, the cinematic Mordecai is a pacifist and he longs for a kind of material progress divorced from violence. He explains to the king:

I dream of the day sire when there will be an end to war. I have been your counsellor, and counsellor to your father Darius and I have seen death and destruction. I thought, how splendid it would be if all of this waste of wealth and man could be turned to building instead of destroying, the building of aqueducts, the irrigation of the desert, the creation of wealth and beauty.

Haman follows up by asking why Jews always wish for such things. Mordecai explains that war has dispersed his people from their homeland. Mordecai as the responsible minister makes reference to the Jewish longing for Zion, in keeping with other biblical books, but, this particular ideology, scarcely reflects the Mordecai of the Bible, as shall be discussed further.

Despite the conservatism of Esther and the King, it does have a similar take on law as the biblical Esther. In both versions of the story, the king and others are constrained by the power of royal edicts. Certain actions, though undesirable and perhaps immoral, are compulsory because of earlier statutes. In the biblical story, these laws are exaggerated for comic effect and the immutability of the laws is probably intended as part of the humorous situation. Day has shown that the different ways that the various characters react to the laws is an essential part of the story. ${ }^{54}$ In the film, familiarity with law is used as a means through which Haman and Mordecai spar. Their particular battles are almost like filmed courtroom scenes, where each one tries to outdo the other with reference to the laws of the kingdoms and their application to specific situations. In the film, Haman and Mordecai represent intellectual heroes that would have been familiar to audiences of 1960, lawyers battling with words and knowledge of case law. The law itself is not a problem that needs to be surmounted as it is in the biblical story. The law, in Esther and the King is venerated and treated seriously. It is the avenue

53 Shepherd, The Bible on Silent Film, 186-7.

54 Day, Esther, 9-10. 
through which proper resolution can be found. The danger that comes with law, in the film, is its improper and immoral application by a dishonest interpreter, in this case, Haman. Thus the law must be treated with respect and the agents of law have a serious responsibility within the proper operation of the state.

The abandonment of the carnivalesque mood and tone of the biblical story is also apparent, to some degree, in Esther and the King's treatment of gender. Here is not so much an inversion of normative behavior as a typical orientalist presentation of sexual excesses of the non-Jewish characters. The perceived eroticism of pagan life is one of the traditional cultural elements that biblical life is juxtaposed with. For a film released in 1960, the scantily clad dancing girls, the toplessness of Vashti and other scenes of harem girls being bathed may have been lascivious (although there is no frontal nudity), and this was not atypical of biblical spectacles, where the subject matter allowed a certain kind of freedom for sexual content involving non-Israelite or non-Christian characters. This is most apparent in early biblical epic. The Sign of the Cross, for example, featured a partially nude Claudette Colbert and implied lesbianism. DeMille's first The Ten Commandments (1923) showcased an orgiastic golden calf scene. By the 1950s, direct sexual content was toned down but beautiful women in exotic garb (that is, minimally clothed) were still one of the main selling points of biblical films for viewers. Esther and the King, when it was originally announced in 1954, was intended as a Hedy Lamarr vehicle (although she dropped out of the project), with her sex appeal the driving artistic vision of the production. The advertising for the film in its final form highlighted Joan Collins's beauty as a draw for audiences, but in a biblical setting that made viewing her beauty almost virtuous. Here Esther and the King is typical of the biblical epics of the 1950s and 1960s. Israelite and Christian women were beautiful but domestic and sexually unaggressive. The pagan characters in the films were likewise beautiful, but sexually aggressive and dangerous. The viewer of such a film could vicariously enjoy both types of depictions and yet still feel virtuous because the film was on a biblical topic.

Returning again to the issue of character inversion, Queen Vashti whose biblical representation has led her to be embraced as a proto-feminist icon in contemporary biblical interpretation, is made into a figure of immorality in the film, more in keeping with traditional Jewish interpretation. ${ }^{55}$ Vashti is presented as a foreign seductress and willing adulterous, typical of the genre of 1950s and 1960s biblical epic. The audience is first introduced to Vashti in a sequence depicting her illicit affair with Haman. In the biblical story, neither character is

55 Carruthers, Esther, 62. 
an adulterer, although Ahasuerus mistakenly believes that Haman has attempted to force himself upon Esther, thereby leading to Haman's fall from royal favor. In the film, the affair between Vashti and Haman serves to demonstrate the extent of Haman's treasonous actions against the king. ${ }^{56}$ Cinematically depicting Haman as an actual adulterer plays on this but shifts the adultery from farcical misinterpretation to treasonous sexual misconduct. In the film, Ahasuerus becomes aware that Vashti has cheated on him while he was away fighting Egypt, but does not realize that Haman is the guilty party. Yet rather than publicly condemning her, Ahasuerus chooses to privately condemn her, in order to save her from execution and retain his own pride. Here Ahasuerus is the figure of the virtuous king, privately acknowledging immorality but allowing himself to suffer for the public good.

That affair should be enough, cinematically, to bring about Vashti's downfall, but the film makes a token effort to at least acknowledge the biblical original. In Esther and the King, Vashti herself chooses to appear before the king during a banquet, the opposite of the situation that is presented in the Bible. In a previous sequence, the king had already made his distaste for dancing girl spectacles clear and so the viewers can expect that he will not respond positively to his wife suddenly appearing. That Ahasuerus frowns on such a display indicates that his values are consistent with conservative American values about female propriety. In a moment that was probably shocking for a 1960s audience, Vashti tears off her top and reveals her breasts to the court. The king throws a robe at her in anger and she is sent from the room. Haman points out that she has shamed the king but this is a different kind of shame than in the biblical original. In the Bible, Vashti humiliates the king because, as his wife, she refuses to obey his command. In the film, she disgraces her husband by revealing her breasts to the court and spitting on the king. The actions of both versions of Vashti could be read as feminist from a 21st-century perspective, yet in the context of 1960, public display of nudity was clearly intended to signify Vashti's deviance. While disobeying her husband, as in the biblical original, might also have connoted deviance to an audience in the 1960s, the king's demand that she present herself nude in front of his court would have been even more deviant, and so out of character for Richard Egan's Ahasuerus.

The prominence of the banquet scene in the biblical story was well suited for cinematic adaptation. One hallmark of the biblical epics of the era was the orientalist banquet scene featuring scantily clad dancing girls. Esther and the

56 Dan Clanton, Daring, Disreputable and Devout: Interpreting the Bible's Women in the Arts and Music (New York: Continuum, 2009), 121. 
King offers two such scenes, with exotic dancing girls gyrating to eastern-themed music (heavy on percussion), while nobles lounge around (in a Roman fashion), eating and drinking. This is the kinetic version of the typical scene of 19th-century orientalist artists, where dancing girls perform for a court in a seductive fashion. Yet, the film breaks with tradition and Ahasuerus is no oriental despot in the fashion of the Victorian imagination. In the filmed party sequences, he brings the dancing to an immediate end, clearly not impressed by the spectacle.

In both the Bible and this film, the unfortunate occurrences at the banquet set in motion the sequence of events that bring Esther to the king's attention. In the Bible, we are simply told that when Ahasuerus remembered that he had banned Vashti from court, his advisors recommended bringing the beautiful women of Persia to the palace so that the king can choose a new queen. The film expands on this information, making the call for a courtly "beauty pageant" emerge from the conflict between Haman and Mordecai. Following upon Vashti's shaming of the king, Haman proclaims that it is his job as chief advisor to the king to find a new wife for the ruler. Mordecai, sensing that Haman is plotting for his own best interest, reminds Ahasuerus that Persian rule requires a contest in which all of the women from the kingdom are brought before him for his evaluation. This, in Mordecai's mind, will prevent Haman from putting his own puppet queen in a position of influence.

Typically, there are two female leads in the genre. There is the woman who worships other gods, is sexually aggressive, morally corrupt, and often plotting to gain more power through nefarious means - in this case Vashti. Her foil is a loyal and chaste heroine, who is firm in her faith to Judaism or Christianity (depending on whether it is an Old or New Testament story) - in this case Esther. Unlike the biblical account, viewers of the film have already been introduced to Esther by the time Mordecai calls for a beauty pageant. Joan Collins plays Esther as a heroine that could be found in any biblical epic of the era. Usually the loyal woman is more of a supporting character than a hero but in keeping with the biblical story, Joan Collins's Esther is the star of the film (she has higher billing than Richard Egan even if he has more screen-time). Yet, this relationship of character foils that links the two women is not so different in the film from the book as it may first seem. What especially differs between the two women are particularly their approaches to handling disagreements with their powerful husbands. ${ }^{57}$ In the biblical book of Esther, much suspense derives from the Persian law that anyone may be sentenced to death if he or she speaks at court without the king having pointed his scepter at them. In both Bible and film, this is the moment where Esther demonstrates her

57 See Day, Esther, 2-3; Berlin, Esther, lv-lvi. 
heroism. In the film, this sequence occurs as Haman's plot to transform the Jews into scapegoats reaches its zenith. Haman engineers the framing of the Hebrews of Persia as traitors and convinces the king to order the execution of Mordecai and his people based on misinformation. By hiding the king's military plans against Macedonia in the Jewish temple, he is able to "discover" evidence that Mordecai has stolen those plans and is working as a spy. Believing the fraudulent evidence against Mordecai, the king sentences the Jews to death. At this point, Esther steps forward and reveals that she is also a Hebrew and asks the king to consider why it is that Haman has revealed this information on the evening before the king intends to march to Persepolis. The king's treasury is in that city and since Haman has been embezzling, he has good reason to not want the king to go there. The king suspends the sentence against the Jews temporarily.

Issues of embezzlement suggest a 20th-century anachronism and other elements of the film further situate the biblical tale in the concerns of contemporary times. As Clanton comments, the biblical story implies that the king has intercourse with the various virgins that he has gathered during his attempt to choose a new wife. ${ }^{58}$ This is changed for the 1960 film. The pageant, in Esther and the King, is run much as was a typical American beauty pageant of the 1950 s. The palace eunuch, Hegai, is played as an effeminate pageant coach, choreographing the movements of the women and working with them to improve their fashion. Esther is reluctant to participate, due to her feelings of loyalty for her fiancé Simon. Indeed, she was taken from her village for the pageant just as she was about to be married. Despite her uncertain feelings about the new situation in which she finds herself, Esther succeeds in gaining the recognition of the king without effort, much to the chagrin of the more competitive (and less morally upright) women in the pageant. The pageant though is never held. The king beholds Esther and chooses her, recognizing in her the traits of loyalty and moral uprightness that he finds impressive. This is a subtle change from the biblical original; Esther, in the film, continues to conform to conservative American expectations of behavior while still becoming an object of desire for the king. The scope of Esther's sexual agency in the biblical original is much greater.

Esther's initial betrothal to Simon is added as a narrative device to prevent her from simply marrying the king, allowing the filmmakers to transform the narrative thrust of the film almost entirely. The addition of a love triangle provides the main character of the film with a greater story arc, although it also removes

58 Clanton, Daring, 126. 
Esther's own sexual agency, makes her the figure acted upon by male characters. Ahasuerus's morally upright personality means that the audience is not going to be as easily convinced that Esther will come to harm in visiting him without permission or that he will actually commit genocide against the Jews. The love triangle also allows the king to make a heroic-romantic sacrifice for the woman he loves. Towards the end of the film, the romantic subplot comes to a near climax in a sword fight between Simon and the king. Fighting amidst the ruins of Persepolis (it is not really clear narratively why Persepolis looks like a ruined Roman city; practically, it is due to the fact that this was an Italian production). The king recognizes Simon and refuses to fight the man who once saved his life (referring to events that occurred at the beginning of the film). During the duel, Ahasuerus learns that Esther was once betrothed to Simon and the king responds by suggesting that Esther has only chosen the king for his position. Simon explains that Esther willingly rejected him for the king one evening, and by admitting this, also makes himself a figure of virtue for the audience. Other events transpire to interrupt the conflict between the two men and so the love triangle remains unresolved with both men acting honorably (and Esther herself is deprived of agency in participating in the resolution). Later, Simon conveniently dies while protecting his people, saving Esther from having to make a choice. Thus when King Ahasuerus returns from defeat in battle against the newly threatening Macedon, a happy romantic ending is possible, even though, presumably, viewers are to believe that Persia will soon be overrun by Alexander the Great. The filmmakers have grafted a romantic plot onto the original story that is entangled with loyalty to the state and ethnic group, like those in 19th-century opera. Audiences could sympathize with characters sacrificing their only emotional happiness for the good of others and all of the characters can be depicted as honorable, even given the complexity of the situation.

\section{One Night with the King (2006)}

Over 40 years after the release of Esther and the King, One Night with the King (2006) offers a distinctly Christian version of the story of Esther that similarly transforms the biblical book into an epic style film. While other cinematic renderings of Esther were also presumably targeted at Christians, One Night with the King was distributed through FoxFaith, Fox's division aimed at Evangelical Christians. The studio purchases independent films that bear an overtly Christian message and typically concentrates on digital release (as opposed to theatrical release). For Reinhartz, the overtness of the Christian context of the film is a striking depar- 
ture from older biblical epics..$^{59}$ Certainly, she is correct in noting that the explicit Christianizing of the story is a deviation from the genre, but many of the older Old Testament epics do, in fact, hint at Christianity anachronistically. This explicitly Christian presentation of Esther has much to do with the original source material, since this film is not directly based on the bible. The film is actually adapted from a novel by Tommy Tenney and Mark Andrew Olsen called Hadassah: One Night with the King, published by Bethany House. Tenney is a popular evangelical preacher and author and this book was a major seller within the Christian book market. It is a book that is very clearly aimed at American Christian women and so it should be expected that the film would capture this sensibility.

In terms of production scale, the filmed version of One Night with the King is certainly a throwback to the older epic tradition. It had a relatively large budget for an independent production and managed to involve some major mainstream screen talents, with John Rhys-Davies as Mordecai, Omar Sharif as Memucan, Peter O'Toole as Samuel, James Callis (of Battlestar Galactica fame) as Haman, and Luke Goss of the 1980s boyband Bros as Xerxes. From a narrative perspective, the film adheres more closely to the biblical story of Esther than Esther and the King, but still deviates in some substantial ways. Given the difficulties that Christian commentators have traditionally had in dealing with the overt Jewishness of the story of Esther, it is not surprising that a cinematic rendering aimed at an evangelical audience would have to make some dramatic changes to the story. Again, the carnivalesque mood of the book is removed from the film.

The filmmakers must have presumed that the audience for this film would already be familiar with the story. The plot of the film is essentially incomprehensible unless one brings some knowledge of the story of Esther to the viewing of the movie. For those that are familiar with the biblical tale, the film provides some interesting approaches to intertexuality. Most apparent is that the film begins with a prologue about Saul, Samuel, and the Amalekites (ISam 15:7-9), explaining Haman's genealogical descent and providing the motivation for his character's hatred of the Jews. Haman is identified as the son of Hammadetha the Agagite in Esther 3:1 and typically commentators have used the story in Samuel to inform their reading of Esther. This film follows that tradition, and Peter O'Toole, playing the prophet, gains top billing in a film where he actually appears on screen for less than a minute. By opening with a scene from Samuel, One Night with the King offers an approach to biblical reading that is typical of intertextual hermeneutics. The referencing of older interpretative traditions is a relatively common means of expanding original biblical stories for film (for example in

59 Adele Reinhartz, Bible and Cinema: An Introduction (New York: Routledge, 2013), 45. 
Darren Aronofsky's 2014 Noah). This allows filmmakers to make changes to the original while still seeming to capture the spirit of the original work by referencing other pre-modern traditions.

Yet given the historical-literalist readings of the Bible that are common in American evangelicalism, this version of Esther does not open with the usual nods to historicity. Perhaps the filmmakers presumed that their audience would already accept the film as historically realistic and so did not feel it necessary to use the tropes that are typically used to invoke veritas in epic cinema. Instead, the film is framed as a fairy tale or fantasy story, with John Rhys-Davies' opening narration explaining that this is the story of how a lowly orphan girl became the queen of Persia. This captures the sense of social inversion that is present in the biblical story but merges it with the fantasy genre conceit common to films like Star Wars. In these stories, the protagonists rise from positions of obscurity and in the process of becoming saviors for a larger group discover more about their own pedigree. One Night with the King is a story within that framework and it emphasizes all of those elements of the Biblical original.

Esther as a character is presented in a manner typical of the protagonists of that genre. Clanton $(2009,131)$ thinks that her character is modeled after the typical "Disney princess," and he is probably correct, even if this was not a conscious choice of the filmmakers. She is a kindly girl, loyal to her uncle who dreams of one day returning to Jerusalem. Here, the film deviates from the Bible in that the book of Esther shows little interest in Israel. ${ }^{60}$ Given the prominence of this theme in other later books of the Hebrew Bible, the fact that return from Exile plays little to no role in the original biblical narrative is quite striking. For the cinema of the 1950s and 1960s, this agnosticism towards Israel is also unusual, where films like Ben-Hur clearly offer support of the present-day state through the depiction of the ancient kingdom. Esther's concern to return to Jerusalem (although interestingly enough not framed as an interest to return to Israel) reflects evangelical interests in and support of the same. These ideological additions to Esther are completely redundant to the narrative of the film and yet are so prominent that they should be read as a reflection of Christian Zionism, especially popular in American evangelical communities. The importance of the relationship between the existence of Israel and biblical prophecy had come to be commonplace in American evangelical popular culture since the late 1990s, following the success of the Left Behind series of books, building on interpretative traditions that had developed since the nineteenth century.

60 Levenson, Esther, 14-5. 
When Esther is brought to the king's palace in One Night with the King, she complains about the beauty and spa treatments, wondering to the eunuch Hegai why the potential future queens are not taught the arts of governance. She takes advantage of the palace's large library of scrolls (that erroneously bear cuneiform lapidary script inked onto papyrus) and reads as much as she can; the film highlights her reading of Gilgamesh and the stories of Jacob's quest for a wife. Through a montage sequence, we are shown that Esther gradually develops an audience within the harem of young women sitting to listen to her read from the scrolls. Unlike the potential biblical readings of Esther as a sexually aggressive heroine who uses her beauty to get what she wants, Esther in One Night with the King enchants the court with her appreciation for literature. Her sense of modesty regarding fashion and jewelry is further evidence of how the heroine conforms to conservative American expectations of gender normative behavior. Esther even uses the Jacob story to court the king by making her intentions to him clear through that analogy and thus the Bible is her choice of seductive mechanism. It is more successful than the fineries through which the other women choose to display themselves. Esther's portrayal here differs from previous cinematic readings of the character, such as in Louis Feuillade's 1910 Esther, where it is the heroine's beauty (and implied sexuality) that allows her to save her people. ${ }^{61}$ The Esther of One Night with the King behaves like an American audience would hope an unmarried female biblical role model would act. She is feminine in her interest in reading and literature yet does not embrace the more materialistic aspects of feminine life, by desiring excessive wealth or displaying herself in an unseemly fashion.

There are hints of a love triangle in One Night with the King, mimicking the type of dramatic expansion of the biblical story used in Esther and the King. However, Esther becomes free to fall in love with the king almost immediately upon her entrance to the palace. For at the same time that she is brought to the palace, her childhood love interest Jesse (with whom she planned to sneak onto a caravan for Jerusalem one day) was also forcibly brought to the palace. With all of the new women being brought to the palace, the kings' advisors decided that more male retainers were needed and so Jesse was forcibly converted into a eunuch. When he meets Esther again in the palace, Jesse mentions that things have now changed irrevocably and so the heroine is now free to fall in love with the king. ${ }^{62}$

61 Shepherd, The Bible on Silent Film, 104-5.

62 In the original novel, Jesse was called Hathach, associated with the character who brings messages between Esther and Mordecai in the Bible. Carruthers $(2008,163)$ notes that the expanded role of this character solves one of the narrative problems of the original story, that Hathach seems to not be surprised by the content of these messages, since he already knows Esther and her uncle. 
As with Esther and the King, the monarch of One Night with the King must be the kind of character that a heroine can fall in love with. This intention for the character is signaled most directly by the casting choice: a former boy band member (theoretically) evokes exactly that kind of appeal. While Bros may not have been a popular band in the United States, the fact that Goss had been able to play that kind of role successfully must have been part of the consideration when cast in the part. So his character is once again altered so much that he is unrecognizable from the Biblical Ahasuerus. In this film, he is called Xerxes (the traditional identification of Ahasuerus) and is said to be the son of Darius, thereby associating him directly with an historically known king. He is again not the boorish drunken figure of comedy that the character is in the Bible. In this film, Xerxes is a buff warrior (often depicted with his shirt off), with long hair and a piercing gaze, an effect intended to make him seem strikingly handsome. Xerxes is an heroic figure, skilled in battle and competent at administration. He is also not the force behind the plots against the Jews in the film; Haman orchestrates these proceedings while the king is away at battle. He is respectful of his people and responsible in his duties. He is not sexually aggressive in the manner in which one would expect of a king with a large harem; Xerxes seems annoyed and disheartened by the various dates he goes on with prospective queens (in a fashion very much like that of the reality television show The Bachelor). After falling in love with Esther, he refuses dalliances with his concubines and one plot point hinges on Esther's mistaken belief that he would still choose to bed them after their marriage. Despite Xerxes' opportunity for sexual promiscuity, he is depicted as a virtuous man, respectful of women. While not a Christian, he embodies the type of man that the filmmakers present as appealing to Christian women. Although not in a "proper" monogamous marriage, he is sexually inactive out of choice, not because of lack of opportunity. The harem and other potentially sexually deviant aspects of his life are due to the historical circumstances and institutions, not out of lustful intention on his part. His society may be decadent but Xerxes himself chooses not to be.

As with the biblical epics of the 1950s, One Night with the King transforms the original biblical story into a veiled commentary on present day politics, specifically American involvement in overseas military conflict. This is apparent in the changes made to the characters and narrative roles of Memucan and Vashti for the 2006 film. Memucan (played by Omar Sharif) is Xerxes' advisor and this minor biblical character is made into a protagonist in this film, even at one point the intended victim of a purposefully foiled assassination plot orchestrated by Haman to implicate the Jews in treasonous activities. In the Bible, Memucan is one of the king's "sages who knew the law" (Esth 1:13) and is the official who 
suggests that Vashti's insubordination might spread to the other women of the kingdom. In the film, this role is greatly expanded and he is one of the king's most trusted military advisors. As a military advisor, Memucan is a proponent of an aggressive military stance towards the enemies of Persia, the Greeks. This is how he comes to be in disagreement with Vashti in the film, for she takes a pacifistic stance. With these changes, the two characters represent two different voices in American politics.

Unlike Esther and the King, Vashti is not a villain in One Night with the King. It is not an affair nor is it an act of sexual disobedience that leads to her expulsion from court. By 2006, the character of the evil foreign seductress no longer works as well as a foil for the heroine. Babington and Evans have shown that after censorship practices were relaxed in film in the 1970s, it was more difficult for implicit sexual content to be included in biblical epics. ${ }^{63}$ By showing sexual content intended for post 1970s audiences, biblical epic filmmakers run the risk of alienating certain groups (as was the case with The Last Temptation of Christ). Yet presenting sexual content through older cinematic tropes is also risky, for it can make the film seem unsophisticated and dated. Vashti's expulsion in One Night with the King still stems from her refusal to appear before the king's courtiers at his banquet but this is an act of political defiance (and as with Esther and the King, the king is not at fault). Vashti, in this film, does not agree with Xerxes' plans for war with Greece and so she holds an alternate banquet, arguing for a policy of peace. When the king commands that she appear, she gives a speech about how she cannot in conscience wear her royal crown in front of his war council. The speech works well to match the biblical verse literally (in Esth 1:11, Vashti is commanded to wear her royal crown before the feasters) but at the same time avoids the implications of sexual impropriety (a command to appear wearing only the crown) that many commentators read into the verse (including the writers of Esther and the King). She is a sympathetic character for the audience but, given the political tendencies in evangelical America, many viewers probably felt that her character was misguided. Her kind of pacifism and demonstration for pacifism would be read by many as dangerous and so Xerxes will have been justified in banishing her from court, although as Clanton notes, the king is saddened to see her removed in such a manner. ${ }^{64}$ The greater justification for her banishment for an American audience in 2006 was her lack of support for the military endeavor of the state and her public questioning of military action. Here Vashti is the dangerous "other" as in Esther and the King, but it is her

63 Babington and Evans, Biblical Epics, 8.

64 Clanton, Daring, 124. 
anti-militarism and questioning of the actions of the state that makes her dangerous, not her sexual impropriety.

Related to the political message of this film, although one that was perhaps not consciously intended by the filmmakers, is the orientalist depiction of the Middle East as a strange but monolithic culture, where virtuous individuals struggle in a decadent society. The 2006 cinematic rendering of Esther goes to great lengths to depict the setting as exotic. The movie was filmed in India and the Indian setting is showcased to great extent. Filming ancient Persia in India is evocative of 19th-century interpretive sensibilities in a number of ways. Before Mesopotamian and Persian visual culture was recovered archaeologically, India stood in for the exotic architecture of that region in artistic receptions. ${ }^{65}$ Artists, like Gustave Moreau, used better known Indian architecture to stand in for Mesopotamian and Persian architecture in their paintings of Old Testament scenes. Yet this use of India points to more problematic 19th-century notions; for here is the typical orientalist trope that all things eastern are monolithic and interchangeable. Related, the costumes of One Night with the King are more Bollywood than the typical pseudo-Bedouin robes that are traditionally the garb of Old Testament cinematic characters. All are evocative of an imagined India. For the evangelical audience of this film, there is no difference presented between India and Persia. Esther is set in the exotic east so all that matters cinematically are that the settings and props reflect an ancient otherness. Over the past 30 years, the east has been understood in evangelical American circles as monolithic, a view that may have informed US foreign policy, ${ }^{66}$ such as in conflating secular Middle Eastern governments like the Ba'ath party with religious movements like al-Qaeda, or in misreading the seriousness of factional divisions amongst the populations of Iraq and Syria. So this particular problem in One Night with the King has more potential to lead to harmful decision-making than what, at first glance, may just seem like a trivial mistake regarding geography.

The evangelical merger of Christian belief and democratic governance is also apparent in One Night with the King. As with Esther and the King, the political critique of this cinematic rendering of Esther is transformed from one satirical of bureaucratized governance to one that does not mock the state apparatus. There is, in this film, the typical disdain of monarchy that is expected of the American biblical epic. As Erin Runions has noted, monarchical sensibilities are often

65 McGeough, The Ancient Near East Volume III, 18.

66 See, e.g. Derek Gregory, The Colonial Present: Afghanistan, Palestine, Iraq (New York: Blackwell, 2004). 
equated with tyrannical values in American cinema. ${ }^{67}$ Hinted at throughout the film is that the Persian monarchy is something that Jews are loyally supportive of but that eventually will give way to an even better form of government. Indeed, the villains of the film, led by Haman, constantly complain about the threat that Greek democracy poses to Persia and they argue that the Jews support this democracy against the Persian state. Most of the plotting against the Jews is predicated upon this sense that the Jews are colluding to merge their monotheism with the democracy of the Greeks. In a torchlit speech, Haman poses the question to the crowd, "Are you equal to a slave?", mocking the sentiment that he claims is espoused by these Greek democrats (showing a very misinformed notion of the nature of ancient Greek democracy). In one instance, Haman refers to the Jewish prophecies surrounding a messiah and states that this is the "very essence" of democracy. Here then, the villains are railing against the Christian democratic values that the evangelical audience of the film could be presumed to hold. Thus Esther is fighting on behalf of Christian democracy through her struggle against Haman. By presenting these as the values the antagonists despise, the filmmakers do not need Esther or Mordecai to make anachronistic pro-Christian speeches themselves.

Yet the political conservatism of the film does not prevent One Night with the King from commenting on the genocidal implications of the biblical story. While Mordecai does not orchestrate the destruction of the gentiles, as occurs in the biblical version of the story, Haman's plot for the genocide of the Jews is central. Unlike Esther and the King, the potential genocide of the Jews is explicitly informed by the experiences of the Holocaust and the filmmakers go to great pains to portray Haman as a sort of proto-Nazi. This is not atypical of the biblical epic genre, which often features relatively heavy-handed allusions to more recent events or political ideologies; the presentation of Nazism as almost typological is perhaps more overt here than in other films. In an early appearance, Haman bears an amulet evocative of a swastika. It is not identical to a swastika, so as to not be anachronistic, but the shape is unmistakable. The audience is set up to understand Haman's actions through the lens of World War II. Later, Haman holds an anti-Jewish rally, meant to reflect the type of speech that Hitler gave. He also plots with the Persian state to seize Jewish wealth to support the Persian war with democratic Greece. Haman argues that all the Jews should then be executed so that they cannot fight back against the state's confiscation of their wealth.

67 Erin Runions, "The Temptation of Noah: The Debate about Patriarchal Violence in Darren Aronofsky's Noah," in The Bible in Motion: A Handbook of the Bible and its Reception in Film Part 2, ed. Rhonda Burnette-Bletsch (Boston: Walter de Gruyter, 2015), 832. 
Besides, Haman argues, the Jews are colluding with the enemies of Persia. The parallels with Nazism are not subtle and are not intended to be but they do well reflect one of the important ways in which Esther has started to be read after the horrors of the twentieth century.

\section{Conclusions: Teleologies of Democratic Governance and Gender Hierarchies}

Other cinematic renderings of Esther, such as The Book of Esther (2013) make similar kinds of interpretive choices in order to conform to audience expectations about tone and mood. Burnette-Bletsch and Clanton have commented, for example, that the VeggieTales animated Esther: The Girl Who Became Queen (2000) sanitizes the story in ways that are predictable with the genre of children's literature. ${ }^{68} \mathrm{~A} 1986$ Israeli version (Ester) modifies the story to address issues relating to contemporary Israeli-Palestinian relations (and does so explicitly through a dialogue at the end of the film, presented by the actors out of character). The silent films of Louis Feuillade (1910) and Henri Andréani (1913), as well as Raffaele Mertes' 1999's Esther (one instalment in the Time Life series of Bible madefor-television movies), attempt to stay (somewhat) narratively similar to the original in the Hebrew bible, without substantial modifications to the plot of the story as received. Yet all make similar changes to the mood of the book, presenting it as a mostly serious story. Does the study of these receptions of Esther shed any light on the original composition itself? Burnette-Bletsch suggests that this is a possible outcome of this kind of analysis:

Yet, reversing the hermeneutical flow from "reception" to "text" often brings into focus aspects of that text and its interpretive possibilities that previously escaped our attention. At times it can even aid our understanding of the text's "original" historical situation by prompting interpreters to pose new questions or envision previously unconsidered possibilities. ${ }^{69}$

The analysis of the changes that are made to biblical Esther highlights some of the ways that the text is modified to fit the tropes of the biblical epic genre. While the carnivalesque elements of the biblical story are best understood as function-

68 Burnette-Bletsch, “The Bible and Its Cinematic Adaptations”, 145-6; Clanton, Daring, 123, 128.

69 Burnette-Bletsch, "The Bible and Its Cinematic Adaptations": 157. 
ing conservatively, this mood is difficult to capture in film. This genre is a somber one, with an historically-grounded aesthetic of the biblical epic, where heroic men and faithful women participate in larger events in world history. These adaptations of the book, as Jo Carruthers has noted about Esther reception more generally, reflect the "acrobatics that readers have to perform to negotiate the text's instabilities."70 They reflect the social aspects of the text, how it is made and remade by different communities to reflect the values which they would like to imbue the text with or that they imagine the Bible presents. In the case of its reception as a Biblical epic, the story of Esther is reformulated as a seriousseeming story in order to make conservative arguments about the state and about gender roles.

Other changes point to different methods through which different communities can and have read Esther. The explicit connection of Haman with Nazism in One Night with the King represents a consideration of Esther that reflects the difficulties that that text presents in an era when genocide is possible. Ham-fisted though the effort may be in One Night with the King, the treatment of Nazism as an almost typological threat to Judaism is an important message for the intended audience of that film. Perhaps, as Linda Day suggests, in a post-World War II context, it is impossible to read Esther as a mere story and such reflections are essential elements of contemporary reception..$^{71}$ The Nazis are not an overt part of Esther and the King, which is not necessarily surprising given that this was an Italian-made film that was released in 1960. There are hints of anti-authoritarianism in the film, however. Perhaps most noteworthy is the pacifism espoused by Mordecai, which is very typical of the religious figures in epics of the era, reflecting the burgeoning post-war sentiment of the time. Yet given these political messages, it is striking that neither filmed version of Esther under discussion here is particularly concerned with minority rights in the same way as the biblical original. ${ }^{72}$ The films are framed as other biblical epics are, where the ancient Jewish minority group is presented as the precursor of the eventually dominant Protestant American majority. The audience is intended to identify with the Jewish minority characters in the films, and see this phase of history as an earlier stage in a teleology of Christian normativity. There are no real concerns for minority rights here because the minority as presented here is not intended to be universally symbolic of minorities and the audience knows that this minority will eventually triumph.

70 Carruthers, Esther, 6.

71 Day, Esther, 21.

72 See Beal, The Book of Hiding and Day, Esther, 1-2. 
Cinema's power as a means of mass entertainment and information means that these kinds of biblical receptions can be very influential. Neither Esther and the King or One Night with the King were particularly successful and neither has had the power to reshape the reception history of a biblical story in the way that Cecil B. DeMille's 1956 The Ten Commandments has done for what are now generations of viewers. Yet for the cinemagoers of 1960 who saw Esther and the King and the more restricted evangelical audience who One Night with the King was aimed at (although the film's presence on various streaming services suggests that it will continue to gain a larger viewership than it had initially), these films offer readings of the biblical story that will be influential. These films take one form of popular conservatism, the literary carnivalesque, and remake it into another form of popular conservatism, the biblical epic, which will be more readily understandable in its conservatism by contemporary audiences. By presenting conservative views on the state and gender in an ancient biblical setting, the films reify those values and normalize them; the films make those conservative values part of a teleological movement that has culminated in the present. The films show heroic ancient individuals striving to make present day democratic values and gender hierarchies normative and so reinforce those same values for the audience.

\section{Works Cited}

Babington, Bruce, and Peter William Evans. 1993. Biblical Epics: Sacred Narrative in the Hollywood Cinema. Manchester: Manchester University Press.

Beal, Timothy K. 1997. The Book of Hiding: Gender, Ethnicity, Annihilation, and Esther. New York: Routledge.

Berlin, Adele. 2001. Esther [= Ester]: The Traditional Hebrew Text with the New JPS Translation. JPS Bible Commentary; Philadelphia: Jewish Publication Society.

Burnette-Bletsch, Rhonda. 2014. "The Bible and Its Cinematic Adaptations: A Consideration of Filmic Exegesis." Journal of the Bible and its Reception 1(1): 129-160.

Bush, Frederic. 1996. Ruth/Esther. Word Biblical Commentary 9. Dallas: Word Books Publisher.

Camp, Claudia V. 1985. Wisdom and the Feminine in the Book of Proverbs. Bible and Literature Series 11; Sheffield: Sheffield Academic Press.

Carruthers, Jo. 2008. Esther Through the Centuries. Blackwell Bible Commentaries. Malden, MA: Blackwell Publishing.

Carruthers, Jo. 2010. "Biblical Epic and the American State: The Traitor and Sanctified Violence in Esther and the King (1960)." In Holy Terror: Understanding Religion and Violence in Popular Culture, edited by Eric S. Christianson and Hugh Partridge, 42-52. Sheffield: Equinox.

Clanton, Dan. 2009. Daring, Disreputable and Devout: Interpreting the Bible's Women in the Arts and Music. New York: Continuum. 
Craig, Kenneth. 1995. Reading Esther: A Case for the Literary Carnivalesque. Louisville: Westminster John Knox.

Crawford, Sidnie Ann White. 1989. “Esther: A Feminine Model for Jewish Diaspora.” In Gender and Difference in Ancient Israel, edited by. Peggy L. Day, 161-177. Minneapolis: Fortress.

Crawford, Sidnie Ann White. 1998. "Esther." In Women's Bible Commentary, edited by Carol A. Newsom and Sharon H. Ringe, 124-129. Louisville: Westminster John Knox.

Day, Linda. 2005. Esther. Abingdon Old Testament Commentaries. Nashville: Abingdon Press.

Forshey, Gerald E. 1992. American Religious and Biblical Spectaculars. Media and Society Series. Westport, Connecticut: Praeger.

Frei, Hans. 1974. The Eclipse of Biblical Narrative: A Study of Eighteenth and Nineteenth Century Hermeneutics. New Haven: Yale University Press.

Gregory, Derek. 2004. The Colonial Present: Afghanistan, Palestine, Iraq. New York: Blackwell. Jarick, John. 1997. “The Bible's ‘Festival Scrolls' among the Dead Sea Scrolls.” In The Scrolls and the Scriptures: Qumran Fifty Years Later, edited by Stanley E. Porter and Craig A. Evans. Journal for the Study of the Pseudepigrapha Supplement Series 26; Roehampton Institute London Papers, 3, 170-182. Sheffield: Sheffield Academic Press.

Klein, Lillian R. 2003. From Deborah to Esther: Sexual Politics in the Hebrew Bible. Minneapolis: Fortress.

Levenson, Jon D. 1997. Esther. Old Testament Library (OTL); Louisville: Westminster John Knox.

Mander, Jerry. 1978. Four Arguments for the Elimination of Television. New York: Morrow Quill Paperbacks.

McGeough, Kevin M. 2006. "Heroes, Mummies, and Treasure: Near Eastern Archaeology in the Movies.” Near Eastern Archaeology 69: 174-185.

McGeough, Kevin M. 2008. "Esther the Hero: Going beyond 'Wisdom' in Heroic Narratives.” Catholic Biblical Quarterly 70: 44-65.

McGeough, Kevin M. 2015. The Ancient Near East in the Nineteenth Century, Appreciations and Appropriations: Volume III: Fantasy and Alternative Histories. Hebrew Bible Monographs, 69. Sheffield: Sheffield Phoenix Press.

Moore, Carey A. 1971. Esther: Introduction, Translation, and Notes. AB 7B, Garden City, New York: Doubleday.

Paul, Joanna. 2013. Film and the Classical Epic Tradition. Oxford: Oxford University Press. Reinhartz, Adele. 2013. Bible and Cinema: An Introduction. New York: Routledge.

Runions, Erin. 2015. "The Temptation of Noah: The Debate about Patriarchal Violence in Darren Aronofsky's Noah." In The Bible in Motion: A Handbook of the Bible and its Reception in Film, Part 2, edited by Rhonda Burnette-Bletsch, 827-843. Boston: Walter de Gruyter.

Shepherd, David J. 2013. The Bible on Silent Film: Spectacle, Story and Scripture in the Early Cinema. Cambridge: Cambridge University Press.

Singer, Ben. 2001. Melodrama and Modernity: Early Sensational Cinema and its Contexts. New York: Columbia University Press.

Solomon, Jon. 2001. The Ancient World in the Cinema, Revised and expanded edition. New Haven: Yale University Press.

Walsh, Richard. 2003. Reading the Gospels in the Dark: Portrayals of Jesus in Film. New York: Trinity Press International.

Wolfe, Lisa M. 2011. Ruth, Esther, Song of Songs, and Judith. Eugene, Oregon: Cascade Books. 